\title{
Diet and related behaviour of children from disadvantaged schools in Ireland: data from the 2006 Health Behaviour in School-aged Children (HBSC) survey
}

\author{
Colette Kelly, Aoife Gavin, Michal Molcho and Saoirse Nic Gabhainn \\ Health Promotion Research Centre, National University of Ireland, Galway, Galway, Republic of Ireland
}

In 2005 an action plan for educational inclusion, Delivery Equality of Opportunity in Schools (DEIS) was launched in Ireland to ensure the educational needs of children and adolescents from disadvantaged communities are prioritised and effectively addressed. One of the core elements comprise a new integrated School Support Programme (SSP) that will bring together, and build upon, existing interventions for schools and school communities with a concentrated level of educational disadvantage. The School Meals programme is an existing scheme that will continue to provide funding towards provision of food services for disadvantaged schoolchildren.

To investigate the dietary habits and related food behaviours of children attending schools that receive support under the SSP, data from the 2006 Health Behaviour in School-aged Children (HBSC) survey was examined. The overall aim of the HBSC survey is to gain insight into and improve the understanding of the health behaviour and well-being of children and adolescents. HBSC is a school-based survey with data collected through self-completion questionnaires administered in the classroom. HBSC Ireland collected data in 2006 from children aged 9-18 years in primary and post-primary schools ( $n$ 10334). Ethical approval was granted for the study and consent was obtained from schools, parents and children.

Schools that took part in the 2006 HBSC survey were checked against the SSP list provided by the Department of Education and Science $^{(1)}$, resulting in twenty-eight primary and twenty-four post-primary schools. These schools were then matched with schools from the general HBSC sample according to school size, type (e.g. community school) and location (urban or rural). Diet and related lifestyle variables were analysed and compared using $\chi^{2}$ tests.

\begin{tabular}{|c|c|c|c|c|c|c|c|}
\hline$\%$ who report consuming.... & Fruit $>$ once daily & Vegetables $>$ once daily & Sweets $\geq$ daily & Soft drinks $\geq$ daily & Crisps $\geq$ daily & Chips $\geq$ daily & Fish $\geq$ once weekly \\
\hline Disadvantaged schools ( $n$ 2017) & $17.5 * * *$ & $15.3^{* * *}$ & $44.3 * * *$ & $37.0 * * *$ & $21.2 * * *$ & $11.8 * * *$ & $41.6^{*}$ \\
\hline Matched schools ( $n$ 2250) & 21.6 & 19.0 & 36.5 & 23.4 & 13.5 & 6.5 & 45.4 \\
\hline
\end{tabular}

Value was significantly different from that for matched school: $* P<0.05, * * * P<0.001$.

\begin{tabular}{|c|c|c|c|c|c|}
\hline & \multicolumn{3}{|c|}{$\%$ who report never having: } & \multicolumn{2}{|c|}{$\%$ who report: } \\
\hline & $\begin{array}{l}\text { Breakfast on } \\
\text { weekdays }\end{array}$ & $\begin{array}{l}\text { Breakfast with } \\
\text { mother and/or father }\end{array}$ & $\begin{array}{l}\text { Evening meal with } \\
\text { mother and/or father }\end{array}$ & $\begin{array}{l}\text { Watching TV while } \\
\text { having a meal daily }\end{array}$ & $\begin{array}{l}\text { Eating a snack while } \\
\text { watching TV daily }\end{array}$ \\
\hline Disadvantaged schools ( $n$ 2017) & $17.9^{* * *}$ & $37.4 * * *$ & $17.0 * * *$ & $26.9 * * *$ & $27.9 * * *$ \\
\hline Matched schools (n 2250) & 12.5 & 27.8 & 10.9 & 15.6 & 18.1 \\
\hline
\end{tabular}

$\mathrm{TV}$, television. Value was significantly different from that for matched school: $* * * P<0.001$.

Reported dieting behaviour $(12.0 \% v .11 .3 \%)$ and hunger $(16.7 \% v .17 .7 \%)$ were not significantly different between disadvantaged and matched schools respectively.

Results from the survey indicate that children from disadvantaged schools have a poorer diet, less family meal occasions and greater use of television during meal or snack times than those from matched schools. Consideration of a more comprehensive, standardised and compulsory school meal programme for disadvantaged schools is necessary.

HBSC Ireland was funded by the Department of Health and Children, Ireland.

1. Department of Education and Science (2006) Lists of primary and post primary schools in the School Support Programme (SSP) under the DEIS action plan for educational inclusion. http://www.education.ie/servlet/blobservlet/deis_school_list.htm 